\title{
Porównanie statusu konstytucyjnego rządu w Polsce i na Litwie w kontekście semiprezydenckiej formy rządów ${ }^{1}$
}

\author{
Vaidotas A. Vaičaitis \\ Uniwersytet Wileński, Wydział Prawa \\ Katedra Prawa Publicznego
}

\section{Zamiast wstępu}

Przede wszystkim należy stwierdzić, że niniejsze badanie oparte jest wyłącznie na porównaniu tekstów konstytucji (Francji, Polski i Litwy) i nie obejmuje ani praktyki politycznej, ani orzecznictwa konstytucyjnego (doktryny konstytucyjnej), co mogłoby być przedmiotem osobnego badania. Innymi słowy, celem tego opracowania jest omówienie, jak koncepcja i status rządu są rozumiane i jak zostały wyrażone w tekście konstytucji Polski i Litwy w kontekście semiprezydenckiej V Republiki Francuskiej. Takie (po części wydawałoby się formalne) badanie opiera się na definicji konstytucji, która mogłaby być pomocna Sądowi Konstytucyjnemu w interpretacji konstytucji. Nie ma tu miejsca negowanie znaczenia orzecznictwa konstytucyjnego (doktryny konstytucyjnej), jednak autor stoi na stanowisku, że Sąd Konstytucyjny, interpretując konstytucję, powinien przede wszystkim uzasadnić na podstawie przepisów samej konstytucji, dlaczego postanowił odwołać się (lub nie odwołać się) do swoich wcześniejszych precedensów. Parafrazując Ronalda Dworkina, autor zachęca do „poważnego przyjrzenia się” samej konstytucji i określonemu w niej statusowi rządu. W pierwszej części opracowania został omówiony status konstytucyjny Rządu we Francji w oparciu o Konstytucję z 1958 r., w drugiej - podobieństwa statusu konstytucyjnego rządów w Polsce i na Litwie, w trzeciej zaś różnice w kontekście semiprezydenckiej formy rządów. Tekst kończą wnioski, w których podsumowano podobieństwa i różnice między rządami w Polsce i na Litwie w kontekście francuskiego modelu systemu semiprezydenckiego.

1 Chciałbym wyrazić moją wielką wdzięczność Teresie Daleckiej za przetłumaczenie tego artykułu na język polski. W artykule zostaną przeanalizowane podobieństwa i różnice w konstytucjach Polski i Litwy. Zob. V. A. Vaičaitis, Status konstytucyjny prezydentów Litwy i Polski, [w:] D. Górecki (red.), Instytucja prezydenta w polskim i litewskim prawie konstytucyjnym, Łódź 2017, s. 195-208. 
Pierwotna hipoteza niniejszego badania jest taka, że status konstytucyjny rządów $\mathrm{w}$ dwóch sąsiadujących państwach jest $\mathrm{w}$ zasadzie taki sam, a podobieństwa są uwarunkowane ustrojem unitarnym i zorientowaniem na francuską semiprezydencką (według modelu wymyślonego przez Duvergera) formę rządów, w ramach której władzę wykonawczą sprawuje bezpośrednio wybierany Prezydent i Rząd, podległy parlamentowi. W tym miejscu można jedynie wspomnieć, że obrana w Konstytucji de Gaulle’a z 1958 r. konstrukcja współdziałania władz została później nazwana przez przedstawicieli nauk politycznych „semiprezydencką” formą rządów. Z kolei przed około trzydziestoma laty znaczna część krajów Europy Środkowej i Wschodniej (w wyniku demokratyzacji), w tym Polska i Litwa, obrała taką samą formę rządów. Dlaczego tak się stało? Zapewne nie ma na to jednoznacznej odpowiedzi, lecz jednym $z$ argumentów mogłoby być to, że krajom, które wyzwoliły się z autorytaryzmu bezpośrednio wybierany Prezydent i samodzielny Sąd Konstytucyjny wydawały się tą dźwignią „parlamentaryzmu racjonalnego”, która miała zapewnić odpowiedni bilans we współdziałaniu władz w nowych demokracjach.

Przed rozpoczęciem omawiania konstytucji konkretnych krajów należałoby zwrócić uwagę na pewne paradoksy: z jednej strony, status rządu zazwyczaj nie może być łączony z przedstawicielstwem suwerennej władzy, jak jest w przypadku organu Prezydenta, parlamentu czy Sądu Konstytucyjnego, jednak z drugiej - pewnie nie istnieje żaden inny organ publiczny, z którym ściślej można by było powiązać pojęcie „władzy publicznej” per se. Kolejny paradoks polega na tym, że w wielu przypadkach status prawny rządu określony w konstytucji (de jure) i jego znaczenie w praktyce (de facto) dość znacznie się różnią. Wreszcie trzeci paradoks w pojęciu rządu kryje się w jego niejednoznaczności, gdyż: 1) w najszerszym sensie można go powiązać w całości z organami władzy publicznej; 2) w nieco węższym sensie może obejmować w całości władzę wykonawczą lub przynajmniej instytucję Prezydenta łącznie z Gabinetem Ministrów (taka koncepcja rządu była przewidziana w Konstytucji Litwy z 1922 r.), 3) wreszcie, w najwęższym sensie oznacza po prostu Gabinet Ministrów (tj. Prezesa Rady Ministrów i ministrów)². Właśnie w tym ostatnim rozumieniu koncepcja rządu będzie najczęściej przywoływana w tym opracowaniu.

2 Na tę niejednoznaczność pojęcia rządu zwrócił uwagę Egidijus Šileikis w książce Alternatyvi konstitucinè teisè, Vilnius 2005, s. 474-475. 


\section{Status konstytucyjny Rządu we Francji w świetle Konstytucji z 1958 r.}

W tej części zostanie omówiony status konstytucyjny rządu na podstawie Konstytucji Francji po to, by w następnych można było określić wpływ przepisów tej półprezydenckiej Konstytucji na przepisy konstytucji Litwy i Polski, które dotyczą rządu. Należy zaznaczyć, że Konstytucja Francji ${ }^{3}$ z 1958 r., w odróżnieniu od większości współczesnych demokratycznych konstytucji, mogłaby zostać scharakteryzowana jako „konstytucja władzy wykonawczej”, gdyż nie zawiera osobnego rozdziału poświęconego prawom człowieka, natomiast jej rozdział drugi jest poświęcony Prezydentowi, trzeci - Rządowi i dopiero następny, czwarty rozdział, dotyczy parlamentu. Ponadto, w tej konstytucji jest rozdział V: O stosunkach między Rządem a parlamentem oraz rozdział X: O odpowiedzialności karnej członków Rza$d u$. Jak zobaczymy dalej, taka strukturalna logika dominacji władzy wykonawczej widoczna jest w treści Konstytucji Francji.

\subsection{Cechy ogólne statusu konstytucyjnego rządu na podstawie Konstytucji Francji}

Można wyróżnić cztery cechy ogólne konstytucyjnego pojęcia Rządu we Francji. Przede wszystkim należy zaznaczyć, że jedną z cech szczególnych rządu, zawartych w Konstytucji Francji, jest to, iż przewidziano dwie formy jego funkcjonowania: gdy kieruje nim premier, jest zwany „Rządem” (franc. Gouvernement), natomiast gdy kieruje nim Prezydent, jest zwany „Radą Ministrów” (franc. Conseil des ministres). Po drugie, status konstytucyjny Rządu we Francji zawiera w sobie zarówno elementy parlamentarnej, jak i prezydenckiej formy rządów. Po trzecie, Rząd we Francji jest nie tylko podstawowym organem władzy wykonawczej, lecz także dominuje (w stosunku do parlamentu) w procesie ustawodawczym. Po czwarte, niezależnie od tego, że najważniejszym urzędnikiem państwowym we Francji jest Prezydent, to jednak Konstytucja Francji określa szczególną rolę premiera w konstrukcji władzy publicznej.

Zgodnie zatem z Konstytucją Francji terminem „Rząd” określa się premiera i ministrów, zaś gdy w tej konstytucji używany jest termin „Rada Ministrów”, to oznacza on wspólne działanie Prezydenta z premierem i pozostałymi ministrami ${ }^{4}$. W takim

3 Tekst Konstytucji Francji z poprawkami zob. na stronie Rady Konstytucyjnej: https://www. conseil-constitutionnel.fr/le-bloc-de-constitutionnalite/texte-integral-de-la-constitutiondu-4-octobre-1958-en-vigueur (dostęp: 20.10.2018).

4 Co prawda, należy od razu zauważyć, że instytucja „Rządu” jest dla tekstu konstytucji ważniejsza, gdyż została wspomniana przynajmniej 60 razy, natomiast „Rada Ministrów” jedynie 
przypadku Rada Ministrów jest nie tylko organem politycznym, ale też podmiotem stanowienia prawa, uprawnionym do przyjmowania aktów prawnych o charakterze wykonawczym (ordonnances et decréts) oraz przygotowywania projektów ustaw rządowych. Ponadto najwyżsi urzędnicy organów publicznych, w tym nie tylko urzędnicy organów centralnych, lecz także członkowie Rady Państwa, Izby Rachunkowości, generałowie, ambasadorzy i inni funkcjonariusze są mianowani właśnie przez Radę Ministrów, nie zaś jednoosobowo przez Rząd czy Prezydenta. Tak samo Rada Ministrów (tj. podczas posiedzenia Prezydenta z członkami Rządu) podejmuje decyzje o wprowadzeniu w kraju stanu wyjątkowego (art. 36).

Po drugie, niejednoznaczność statusu Rządu we Francji ujawnia się również $\mathrm{w}$ tym, że zgodnie z tradycją parlamentaryzmu Rząd Francji podlega parlamentowi, z kolei Zgromadzenie Narodowe może wyrazić wobec niego wotum nieufności (poza tym premier i ministrowie kontrasygnują poszczególne akty wydawane przez Prezydenta, co w okresie kohabitacji politycznej może być traktowane jako forma kontroli parlamentarnej). Jednak z drugiej strony, zgodnie z cechującym prezydencką formę rządów surowszym modelem podziału władz, Prezydent jest wybierany bezpośrednio, zaś członkowie Rządu nie mogą być jednocześnie posłami do parlamentu.

Omawiając trzecią cechę, należy podkreślić, że statusowi Rządu poświęcono aż trzy rozdziały Konstytucji Francji. Są to: rozdział III: Rząd, rozdział V: O stosunkach między Rządem a parlamentem oraz rozdział X: O odpowiedzialności karnej członków Rządu. W art. 20 Konstytucji wyraźnie stwierdzono, że to właśnie Rząd określa i prowadzi politykę Narodu (franc. Le Gouvernement détermine et conduit la politique de la nation), a do realizacji tego celu dysponuje administracją i siłami zbrojnymi. Jest to przepis o charakterze ogólnym, określający ogólne (nie zaś atrybutywne) kompetencje Rządu jako władzy wykonawczej, których nie da się ustalić do końca ${ }^{5}$. Ponadto, jedynie Rząd (nie zaś inny organ) zgodnie z Konstytucją powinien wykonywać i wykonuje swój „program” (art. 38, 49-50). O szczególnym statusie Rządu świadczy też istnienie po nowelizacji Konstytucji w 1993 r. wspomnianego rozdziału X: O odpowiedzialności karnej członków Rządu, przewidującego instytucję quasi-impeachmentu, która ma zastosowanie wyłącznie do członków Rządu (premiera oraz ministrów) za przestępstwa i wykroczenia karne popełnione w ramach sprawowania funkcji członka Rządu. W takim przypadku

około 10 razy. Ustawy przewidują też rozszerzony skład Rządu, gdy na posiedzenia są zapraszani nie tylko ministrowie, lecz także ministrowie bez teki (ministres d'Etat - tytuł honorowy nadawany osobie za zasługi na służbie publicznej), ministrowie delegowani (ministres délégués) i sekretarze stanu (secrétaires d'Etat). Rząd w takim rozszerzonym składzie może liczyć do 43 członków. Zob. np. D. Turpin, Droit Constitutionnel, Paris 1999, s. 405; E. Jarašiūnas, Prancūzijos Respublikos konstitucinè sistema, [w:] Europos Sajungos valstybių narių konstitucinès sistemos, Vilnius 2012, s. 716.

5 Na to zwrócili uwagę również brytyjscy komparatyści: W. Cairns, R. McKeon, Introduction to French Law, London 1995, s. 110-111. 
odpowiedzialność karną stosuje powołany specjalnie na taki przypadek ad hoc organ, tj. Trybunał Sprawiedliwości Republiki (franc. Cour de justice de la République). Zgodnie z Konstytucją Francji wyłącznie immunitet Prezydenta kraju jest chroniony w wyższym stopniu.

Jak już zostało wspomniane, szczególny status Rządu we Francji mógłby być powiązany również z dominacją względem parlamentu w dziedzinie ustawodawczej, co najlepiej pokazane jest w rozdziale V Konstytucji: O stosunkach między Rządem a parlamentem. Przede wszystkim na podstawie art. 34 i 37 można wnioskować, że ustawodawca posiada nie ogólne, lecz atrybutywne kompetencje ustawodawcze, wszystko zaś, co nie zostało określone w art. 34, należy wyłącznie do kompetencji władzy wykonawczej (franc. caractère réglementaire). $\mathrm{Z}$ art. 39 dowiadujemy się, że Rząd (a raczej Rada Ministrów) nie tylko przygotowuje projekty ustaw, ale też de facto opracowuje porządek obrad posiedzeń izby parlamentarnej (franc. lordre du jour). Poza tym Rząd ma dość szerokie uprawnienia nacisku na parlament w kwestii przyjęcia budżetu państwowego (zob. art. 47 i 47-1) i nawet może zażądać od parlamentu głosowania za konkretnym projektem, wiążąc to głosowanie $\mathrm{z}$ zaufaniem wobec Rządu ${ }^{6}$. Co więcej, zgodnie $\mathrm{z}$ art. 38 parlament może powierzyć Rządowi tymczasowe kompetencje wydawania ordonansów regulujących stosunki przyznane w Konstytucji kompetencji ustawodawcy. Co prawda, takie akty władzy wykonawczej powinny być uchwalane na posiedzeniu Rady Ministrów (tj. pod przewodnictwem Prezydenta), później zaś - ratyfikowane przez parlament. Należy też wspomnieć, że Rząd (a dokładniej: premier) ma szerokie uprawnienia na Spotkanie Przewodniczących (franc. Conférences des présidents), gdy istnieje potrzeba rozstrzygania nieporozumień między izbami parlamentu w sprawie projektów ustaw.

Wreszcie, mówiąc o szczególnym statusie konstytucyjnym premiera Francji, należy zaznaczyć, że najlepiej ujawnia się on de facto w okresie kohabitacji politycznej. Jak już zostało zauważone, premier we Francji ma szerokie uprawnienia w procesie ustawodawczym, w koordynacji poszukiwań kompromisów w razie nieporozumień między Rządem a izbami parlamentu. Ma on też prawo inicjatywy ustawodawczej. Poza tym zgodnie z Konstytucją to właśnie premier (a nie Rząd) sprawuje władzę wykonawczą (franc. il exerce le pouvoir réglementaire) oraz „zapewnia wykonanie ustaw" (franc. assure lexécution des lois). W Konstytucji przewidziano, że premier mianuje funkcjonariuszy cywilnych i wojskowych, a także to on (a nie Prezydent jako zwierzchnik sił zbrojnych lub minister obrony) jest odpowiedzialny za obronę kraju, w niektórych zaś przypadkach może zastępować Prezydenta jako zwierzchnika sił zbrojnych, przewodnicząc radom i komitetom Obrony Narodowej. Poza tym premier w Konstytucji został określony jako funkcjonariusz, z którym Prezydent powinien skonsultować się przed wprowadzeniem stanu wojennego na podstawie

6 Gintaras Kalinauskas określa to „Szantażowaniem” Zgromadzenia Narodowego. Zob. G. Kalinauskas, Parlamentinè kontrolè. I/ dalis: Praktika, Vilnius 2011, s. 141-145. 
art. 16 Konstytucji Francji. Szef Rządu w wyjątkowych przypadkach może też przewodniczyć Radzie Ministrów, zastępując Prezydenta. Warto podkreślić, że premier (po konsultacjach z przewodniczącymi obu izb) może podjąć decyzję o wydłużeniu czasu posiedzeń plenarnych parlamentu, zwołać nadzwyczajne lub zamknięte posiedzenie parlamentu (art. 28, 29 i 33). Wreszcie, nawet inicjatywa nowelizacji Konstytucji Francji należy nie tylko do posłów, ale też do Prezydenta, działającego w odpowiedzi na propozycję premiera. $Z$ treści wymienionych kompetencji konstytucyjnych premiera Francji wynika zatem, że jest on nie tylko wcieleniem Rządu, lecz w wielu przypadkach ma też dźwignię wyrażania inicjatywy zarówno przez władzę wykonawczą, jak i ustawodawczą.

\subsection{Stosunki rządu z innymi organami (Prezydentem i Radą Konstytucyjną) zgodnie z Konstytucją Francji}

Już wspomniano, że Konstytucja V Republiki Francuskiej, zwłaszcza po nowelizacji z 1962 r., stworzyła semiprezydencką formę rządów, w ramach której w razie „kohabitacji politycznej” (gdy bezpośrednio wybrany Prezydent i premier reprezentujący większość Zgromadzenia Narodowego należą do różnych partii politycznych) pojawia się tzw. władza wykonawcza „dwóch głów”. Niezależnie od tego tekst Konstytucji przewiduje dość ścisłą więź konstytucyjną między Prezydentem i Rządem (oraz premierem). Termin „Rząd” w Konstytucji Francji po raz pierwszy pojawia się właśnie w art. 7, dotyczącym wyborów prezydenckich. Artykuł głosi, że wybory zarządza Rząd; poza tym przewidziano prawo Rządu tymczasowego pełnienia w poszczególnych przypadkach funkcji Prezydenta.

$\mathrm{W}$ art. 8 Konstytucji Francji przewidziano, że Prezydent powołuje premiera, a na jego wniosek - pozostałych członków Rządu. Należy zauważyć, że „słynny” art. 11 Konstytucji Francji uprawnia Prezydenta (ale jedynie na wniosek Rządu) do ogłoszenia referendum, w którym Prezydent może prosić wyborców o poparcie dla dowolnego rządowego projektu ustawy związanej z władzą publiczną albo polityką ekonomiczną lub społeczną. Co prawda, ten artykuł Konstytucji w ostatnim czasie nie jest stosowany - wiązany jest raczej z praktyką pierwszego Prezydenta V Republiki Francuskiej, de Gaulle’a, niż obecną rzeczywistością konstytucyjną Francji. Wreszcie, jak wspomniano wyżej, zgodnie z art. 19 Konstytucji Francji, pewna część aktów Prezydenta wymaga kontrasygnaty premiera lub właściwego ministra.

Kolejną szczególną cechą Konstytucji Francji z 1958 r. jest status Rady Konstytucyjnej (Conseil Constitutionnel), która według pierwotnego pomysłu generała de Gaulle’a powinna być organem chroniącym władzę wykonawczą przed możliwością parlamentu w zakresie rozszerzenia ustawowo swoich kompetencji i doprowadzenia w taki sposób do zmiany w określonym w konstytucji bilansie między władzą ustawodawczą i wykonawczą. Dlatego kompetencje Rządu wystąpienia 
do Rady Konstytucyjnej wyróżniają się swoim dużym zakresem. Zgodnie z Konstytucją Francji premier ma prawo zwrócić się do Rady Konstytucyjnej w kwestii uprzedniej kontroli konstytucyjnej zarówno ustaw, jak i umów międzynarodowych (art. 54 i 61). Ponadto, zgodnie z art. 39 Konstytucji Francji, w razie niezgodności między premierem i przewodniczącymi obu izb w kwestii przedmiotu regulacji projektów ustaw lub powierzonej procedury ustawodawczej Rząd jest uprawniony do odwołania się do Rady Konstytucyjnej. Rząd ma też prawo wnioskować o skrócenie terminu wydania przez Radę Konstytucyjną decyzji z 30 do 8 dni. Wreszcie, zgodnie z art. 7 Konstytucji Francji, Rząd może wystąpić do Rady Konstytucyjnej również z zapytaniem, czy Prezydent (ze względu na stan zdrowia lub inne okoliczności) może pełnić swoje funkcje.

\section{Podobieństwa statusu konstytucyjnego rządu w konstytucjach Polski i Litwy}

Po omówieniu francuskiej konstytucyjnej koncepcji rządu, poniżej analizowany jest określony w konstytucjach Polski i Litwy status rządu w kontekście wspomnianej koncepcji.

\subsection{Status rządu w strukturze konstytucji Polski i Litwy}

Co ciekawe, w strukturze konstytucji Polski i Litwy status rządu ujęto w dość podobny sposób. W Konstytucji Litwy ${ }^{7}$ ten organ władzy wykonawczej jest, co prawda, wprost nazywany „Rządem”, natomiast w Konstytucji RP - „Radą Ministrów”, mimo że w obu przypadkach składa się z premiera i ministrów ${ }^{8}$. Po drugie, Rząd został wspomniany już w pierwszym rozdziale obu konstytucji (w Konstytucji Litwy został on zatytułowany „Państwo Litewskie”, z kolei w dokumencie polskim - „Rzeczpospolita”), gdzie Rząd (w Polsce bezpośrednio, na Litwie - pośrednio) jest elementem władzy wykonawczej. Co więcej, obie konstytucje do władzy wykonawczej zaliczają nie tylko Rząd, ale także instytucję Prezydenta (wybieranego bezpośrednio). Jak już zostało wspomniane, w przypadku polskiej Konstytucji zo-

7 „Valstybès žinios” z 1992 r., nr 33-1014.

8 W Konstytucji RP z 1997 r. szef rządu nazywany jest „Prezesem Rady Ministrów”, natomiast w niniejszym opracowaniu będzie używany termin „premier”. Co ciekawe, zgodnie z Konstytucją Litwy z 1922 r. w skład Rządu Litwy wchodził nie tylko Gabinet Ministrów, ale też Prezydent. W tymczasowej ustawie podstawowej Litwy z 1990 r. pojawiły się oba terminy: zarówno „Rząd”, jak i „Rada Ministrów”. „Valstybės žinios” z 1990 r., nr 9-224. 
stało to wskazane explicite, natomiast litewskiej - implicite. I tak, art. 5 Konstytucji Litwy głosi, że „władzę państwową na Litwie sprawuje Sejm, Prezydent Republiki, Rząd i Sąd”, z kolei w art. 10 Konstytucji RP stwierdzono, że „władzę wykonawczą sprawuje Prezydent Rzeczypospolitej Polskiej i Rada Ministrów”.

Należy zauważyć, że zarówno używany w Konstytucji Litwy termin „Rząd”, jak i używany w Konstytucji RP termin „Rada Ministrów” pojawia się w konstytucjach nie tylko we wspomnianym wąskim znaczeniu, tj. mając na względzie kolegium ministrów, ale również w sensie szerokim, tj. biorąc pod uwagę wszystkie działające $\mathrm{w}$ kraju ministerstwa ${ }^{9} \mathrm{i}$ koordynowane przez nie organy władzy wykonawczej. W tym znaczeniu Rząd został wspomniany np. w art. 94 pkt 1 Konstytucji Litwy, w którym czytamy, że „strzeże nienaruszalności terytorium Republiki Litewskiej, gwarantuje bezpieczeństwo państwa i porządek publiczny”. Chociaż termin „Rada Ministrów” w Konstytucji RP odsyła do Rządu w „wąskim” znaczeniu, to jednak $\mathrm{w}$ art. 146 ust. 4 wskazano również szersze jego pojęcie, twierdząc, że w Polsce Rada Ministrów zapewnia bezpieczeństwo wewnętrzne i zewnętrzne oraz porządek publiczny (co więcej, w szerokim sensie używany jest w Konstytucji RP także termin „administracja rządowa” ${ }^{10}$.

Innym strukturalnym podobieństwem $\mathrm{w}$ obu konstytucjach jest szczególne miejsce rozdziału dotyczącego Rządu: w dokumencie litewskim jest to VI, zaś polskim - VII rozdział. W obu przypadkach rozdział poświęcony Rządowi pojawia się po rozdziałach dotyczących parlamentu i Prezydenta, a różnica w numeracji pojawia się z tego względu, że w Konstytucji RP dodany został osobny (trzeci) rozdział pt. Źródła prawa, którego nie ma w Konstytucji Litwy ${ }^{11}$.

Na podstawie tekstu obu konstytucji można wnioskować, że to właśnie Rząd, nie zaś Prezydent stanowi główną instytucję władzy wykonawczej. Do takiego wniosku można dojść nie tylko na podstawie przydzielonych Rządowi szerokich uprawnień konstytucyjnych (na Litwie - art. 94, w Polsce - art. 146), ale też na podstawie tego, że w obu konstytucjach jedynie Rządowi (a nie np. Prezydentowi) przypisany jest „program” działalności. Ponadto, w obu konstytucjach przewidziano tzw. ogólne, nie zaś atrybutywne (ang. residual) kompetencje Rządu ${ }^{12}$ : art. 94 Konstytucji Litwy nie zawiera końcowego wykazu uprawnień Rządu, informując, że Rząd „zarządza sprawami kraju i [...] wykonuje inne obowiązki, nałożone przez

9 Pojęcie ministerstw nie pojawia się w Konstytucji Litwy, jednak w jej art. 67 pkt 8 wskazano, że ministerstwa tworzy Sejm na wniosek Rządu. Jeżeli zatem Rząd nie wystąpił z odpowiednią propozycją utworzenia ministerstwa, Sejm nie może tego zrobić. Zob. A. Pumputis, Lietuvos Respublikos Vyriausybe், [w:] Lietuvos konstitucinè teisè. Vadovèlis, Vilnius 2012, s. 676.

10 Można zauważyć, że na Litwie i w Polsce, podobnie jak w innych krajach europejskich, znaczenie terminu „Rząd” nie obejmuje całego sektora publicznego, jak np. amerykański termin Government.

11 W litewskiej Konstytucji ten szczególny rozdział został wprost zatytułowany: Rzqd Republiki Litewskiej, natomiast w polskiej: Rada Ministrów i administracja rządowa.

12 Zob. także: E. Šileikis, Alternatyvi konstitucinè teisė..., s. 477. 
Konstytucję i ustawy”. Podobnie art. 146 ust. 2 Konstytucji RP głosi, że do Rządu należą sprawy polityki państwa nie zastrzeżone dla innych organów państwowych i samorządu terytorialnego.

W takim kontekście „podobieństw” obu konstytucji można wyróżnić też zasadę solidarności rządów, polegającą na tym, że po dymisji premiera (lub wyrażeniu wobec niego wotum nieufności) do dymisji powinien podać się w całości gabinet ministrów ${ }^{13}$. Co prawda, należy w tym miejscu poczynić drobną uwagę, że w Konstytucji Litwy (przynajmniej teoretycznie) przewidziano jeszcze większy poziom solidarności członków Rządu, polegający na tym, że Rząd Litwy powinien od nowa uzyskać od Sejmu uprawnienia do działania, gdy dochodzi do zmiany ponad połowy ministrów. Jednak nie może to być traktowane jako poważna różnica w statusie Rządu, gdyż zarówno w przypadku Litwy, jak i Polski skład oraz los Rządu zależy od woli większości sejmowej.

Należy zauważyć, że tekst obu konstytucji nie wskazuje, z jakich ministrów powinien składać się Rząd lub - inaczej to ujmując - jakie ministerstwa powinny funkcjonować w kraju. Należy to do uznania ustawodawcy ${ }^{14}$, jednak w Konstytucji RP wspomniany jest minister obrony narodowej (art. 134), sprawiedliwości (art. 187) i pośrednio - spraw zagranicznych (art. 133 ust. 3), z kolei w Konstytucji Litwy - jedynie minister ochrony kraju (art. 140).

Wreszcie jeszcze jedno podobieństwo związane ze statusem konstytucyjnym Rządu (w szerokim sensie) polega na tym, że w obu państwach Prezydent może rozpuścić Sejm w przypadku konfliktu między Rządem i Sejmem. Tak zgodnie $\mathrm{z}$ artykułem 58 Konstytucji Litwy Prezydent może ogłosić przedterminowe wybory parlamentarne, jeżeli Sejm nie popiera programu Rządu lub wyraża wobec niego wotum nieufności. Takie samo prawo ma też Prezydent RP zgodnie z art. 155 ust. 2 Konstytucji Polski ${ }^{15}$.

\subsection{Tworzenie rządu i kontrola parlamentarna nad nim}

Jak już zostało wspomniane, konstytucje obu państw przewidują semiprezydencką formę rządów, dlatego zarówno rząd Polski, jak i Litwy zazwyczaj są tworzone po wyborach parlamentarnych, z uwzględnieniem ich wyników. Poza tym, Rząd

13 Można zauważyć, że zgodnie z art. 162 Konstytucji RP Prezydent Rzeczypospolitej ma dyskrecję nieprzyjęcia dymisji premiera.

14 Zob. także: B. Banaszak, The System of Government in Poland, [w:] N. Chrpnowski, T. Dronoczi, T. Takacs (red.), Governmental Systems of Central and Eastern European States, Warszawa 2011, s. 531.

15 Co prawda, na Litwie Prezydent powinien zachować znacznie większą ostrożność, podejmując decyzję o przedterminowym rozwiązaniu Sejmu, gdyż zgodnie z Konstytucją Litwy nowy Sejm głosami trzech piątych swoich członków może ogłosić przedterminowe wybory prezydenckie (art. 87 ust. 1). 
podlega Sejmowi, gdyż zyskuje uprawnienia do pracy dopiero po tym, gdy Sejm zaakceptuje jego program. Ponadto Rząd (lub konkretny minister) powinien podać się do dymisji, jeżeli Sejm (większością głosów posłów) wyraża Rządowi lub konkretnemu ministrowi wotum nieufności.

W obu konstytucjach przewidziano, że po wyborach parlamentarnych lub dymisji Rządu Prezydent nominuje (na Litwie - wyznacza) premiera, który według własnego uznania powołuje pozostałych ministrów. Następnie Prezydent, na wniosek premiera, powołuje cały Rząd, który zyskuje pełnomocnictwa do pracy dopiero po akceptacji Sejmu i złożeniu przysięgi przez ministrów. Do tego, by Rząd rozpoczął pracę, na Litwie Sejm powinien zaakceptować program Rządu (art. 92 ust. 5), z kolei Sejm w Polsce bezpośrednio głosuje w kwestii wotum zaufania wobec Rządu (art. 154 ust. 2). Poza tym, w Konstytucji RP przewidziana jest możliwość samodzielnego wyboru premiera przez Sejm i przedstawienia jego kandydatury Prezydentowi, jeżeli powołany przez Prezydenta premier i jego zespół nie zyskały poparcia Sejmu. Gdyby w takim przypadku Sejm w Polsce nie poparł nowego Rządu, może go samodzielnie utworzyć Prezydent ${ }^{16}$. Obie konstytucje przewidują, że dla zatwierdzenia Rządu wystarczająca jest większość głosów parlamentarzystów biorących udział w posiedzeniu Sejmu, z kolei w celu wyrażenia wotum nieufności wymagane są głosy ponad połowy posłów.

$\mathrm{W}$ takim kontekście należy zwrócić uwagę na podobne terminy tworzenia Rządu: na Litwie nowo utworzony Rząd powinien być przedstawiony Sejmowi do akceptacji w terminie 15 dni od dnia jego zaaprobowania dekretem Prezydenta (art. 92 ust. 2), podobnie w Polsce Prezydent RP (i powołany przez niego premier) mają 14 dni na utworzenie Rządu, później zaś mianowany przez Prezydenta premier ma kolejne 14 dni na przedstawienie Sejmowi programu Rządu. W obu krajach zatem terminy te są podobne, jednak w Konstytucji RP osobna uwaga (i dłuższy termin) jest poświęcona opracowaniu programu Rządu.

Jak już zostało wspomniane, w obu konstytucjach przewidziano, że członkowie Rządu przed rozpoczęciem pełnienia funkcji powinni złożyć przysięgę. Co prawda, w Polsce przysięgę ministrów odbiera Prezydent RP (art. 154 ust. 1), natomiast litewscy ministrowie składają przysięgę przed Sejmem (art. 93), a przysięgę odbiera Przewodniczący (Marszałek) Sejmu.

Wreszcie, w obu konstytucjach przewidziane są podobne narzędzia kontroli parlamentarnej. W art. 95 Konstytucji RP określono zasadę, zgodnie z którą wyłącznie Sejm sprawuje kontrolę parlamentarną nad Rządem, natomiast art. 115 przewiduje, że parlamentarzyści korzystają z dwóch narzędzi kontroli parlamentarnej: prawa zapytania i interpelacji. Podobnie w art. 61 Konstytucji Litwy czytamy, że z interpelacją wobec premiera lub ministra może wystąpić grupa co najmniej jednej piątej posłów. Co więcej, sprawowana przez komitet sejmowy kontrola nad Rządem jest przewidziana w litewskim akcie konstytucyjnym w sprawie 
członkostwa Republiki Litewskiej w Unii Europejskiej, stanowiącym część składową Konstytucji Litwy. Jednak, jak już wspomniano, najważniejsze narzędzie kontroli parlamentarnej to możliwość wystąpienia przed Sejmem z wotum nieufności wobec poszczególnych ministrów lub Rządu in corpore, co jest przewidziane w obu konstytucjach.

\subsection{Akty rządowe, niemożność pogodzenia stanowiska z pełnieniem funkcji ministra i polityka zagraniczna rządu}

Kolejne podobieństwo między obu konstytucjami wynika z tego, że określono w nich niemożność pogodzenia funkcji ministra z pełnieniem innych obowiązków. W art. 150 Konstytucji Polski ustalono ogólną zasadę, zgodnie z którą minister nie może prowadzić żadnej działalności niezgodnej z jego obowiązkami publicznymi. Podobnie art. 99 Konstytucji Litwy głosi, że ministrowie nie mogą pełnić żadnych innych funkcji z wyboru lub mianowania ani pracować w przedsiębiorstwach, instytucjach handlowych lub innych instytucjach lub zakładach prywatnych, ani też otrzymywać jakiegokolwiek innego wynagrodzenia oprócz przewidzianego z racji sprawowanych obowiązków w Rządzie i wynagrodzenia za działalność twórczą oraz (art. 60) wynagrodzenia za pełnienie funkcji posła na Sejm, jeżeli minister jest jednocześnie członkiem Sejmu. To, że minister może być jednocześnie posłem, przewidziano też w art. 147 ust. 4 Konstytucji RP.

W art. 95 Konstytucji Litwy określono, że Rząd podejmuje decyzje w kwestiach kierowania państwem większością głosów członków uczestniczących w posiedzeniach. Chociaż Konstytucja Polski nie zawiera podobnego przepisu, to jednak zbiorowy charakter podejmowania decyzji może być wywiedziony z ogólnej zasady pracy zbiorowej Rządu (i zbiorowego podejmowania decyzji) ${ }^{17}$. Akty rządowe zarówno na Litwie, jak i w Polsce są traktowane jako akty „wykonawcze”, tj. ich status prawny jest niższy niż ustaw przyjętych przez parlament. Akty rządowe podpisuje premier i właściwy minister.

Jak już wspomniano, jedną z cech szczególnych Konstytucji Polski jest osobny rozdział III, zatytułowany Źródła prawa. W rozdziale tym m.in. czytamy, że jednym z powszechnie obowiązujących rodzajów źródeł prawa są rozporządzenia. Zgodnie z Konstytucją RP rozporządzenia służą do realizacji ustaw, może je uchwalać nie tylko Rząd, ale też Prezydent, premier, poszczególni ministrowie i nawet Krajowa Rada Radiofonii i Telewizji. Z kolei zgodnie z art. 95 Konstytucji Litwy Rząd przyjmuje „uchwały”, których wykonawczy charakter ujawnia się w tym, że zgodnie z art. 94 litewskiej Konstytucji Rząd (przyjmując uchwały) m.in. wykonuje ustawy.

17 B. Banaszak, The Republic of Poland, [w:] C. Kortmen, J. Fleuren, W. Voermans (red.), Constitutional Law of 10 EU Member States, Warszawa 2006, s. VIII-23. 
W tym kontekście można zauważyć, że zarówno ustawa zasadnicza Polski, jak i Litwy przewiduje, że znaczna część rozporządzeń Prezydenta nie wymaga kontrasygnaty członków Rządu. Co prawda, art. 85 Konstytucji Litwy przewiduje zaledwie cztery przypadki, gdy członkowie Rządu powinni kontrasygnować dekrety Prezydenta: premier Litwy ma obowiązek kontrasygnować dekret Prezydenta o wprowadzeniu stanu nadzwyczajnego, z kolei dekrety o mianowaniu i odwołaniu dyplomatów, nadaniu najwyższych stopni wojskowych oraz udzieleniu litewskiego obywatelstwa odpowiednio kontrasygnują minister spraw zagranicznych, obrony kraju i spraw wewnętrznych. Natomiast art. 144 Konstytucji Polski wymienia trzydzieści przypadków, gdy premier Polski nie ma obowiązku kontrasygnowania rozporządzeń Prezydenta RP.

Wreszcie na zakończenie omawiania powyższych podobieństw można stwierdzić, że obie konstytucje zawierają przepis głoszący, iż nie tylko Prezydent prowadzi politykę zagraniczną - należy ona również do kompetencji Rządu. Zgodnie z Konstytucją Litwy Sejm jedynie „rozważa” kwestie polityki zagranicznej, natomiast „prowadzeniem polityki zagranicznej” zajmują się dwa organy: Prezydent i Rząd (art. 84 ust. 1). Podobnie, jak przewiduje art. 146 ust. 1 Konstytucji RP, Rząd prowadzi politykę zagraniczną, a zgodnie z art. 133 ust. 3, Prezydent w zakresie polityki zagranicznej współdziała z premierem i właściwym ministrem (spraw zagranicznych).

\section{Różnice w statusie konstytucyjnym rządu w Polsce i na Litwie}

\subsection{Rada Ministrów i Rada Gabinetowa w Polsce a Rząd Litwy}

Jedna z najciekawszych różnic polega na tym, że - jak już wspomniano wyżej - w Konstytucji Polski w ogóle nie pojawia się termin „Rząd”, a zamiast niego stosowany jest termin „Rada Ministrów”. Nie należy, oczywiście, nadawać temu większego znaczenia, gdyż używa się terminu „administracja rządowa”, dlatego nie można stwierdzić, iż termin „Rząd” ma w Polsce charakter czysto polityczny i nie jest terminem prawno-konstytucyjnym. Artykuł 146 Konstytucji RP głosi, że Rada Ministrów kieruje administracją rządową, zaś określonymi działami administracji rządowej kierują ministrowie (art. 149). Chociaż w Konstytucji RP wyraźnie nie sprecyzowano, co znaczy „administracja rządowa”, jednak z treści artykułu wynika, że obejmuje ona nie tylko centralną administrację i ministerstwa, lecz także jednostki terytorialne w całym kraju (przede wszystkim powiatowo-wojewódzkie organy administracji rządowej), nie obejmuje jednak organów jednostek samo- 
rządu terytorialnego (art. 94 i 166). Na podstawie tekstu Konstytucji RP (art. 148 i 153) można wnioskować, że „administracja rządowa” wiąże się z służbą cywilną, polegającą na pełnieniu funkcji administracji publicznej. Ponadto, Konstytucja RP głosi, że Prezes Rady Ministrów jest najwyższym urzędnikiem administracji rządowej i zwierzchnikiem korpusu służby cywilnej.

Kolejna różnica polega na tym, że polska Konstytucja przewiduje tzw. Radę Gabinetową, która nie istnieje na Litwie. Zgodnie z art. 141 polskiej Konstytucji Prezydent Rzeczypospolitej w sprawach szczególnej wagi może zwołać Radę Gabinetową, złożoną z Prezydenta RP i wszystkich członków Rady Ministrów. Chociaż w Konstytucji RP nie określono kompetencji tego organu, można jednak wnioskować, że jest to organ wyłącznie o charakterze politycznym, który nie tylko nie pełni funkcji Rządu, ale też nie ma uprawnień do uchwalania aktów prawnych. Z kolei na Litwie Prezydent nie ma uprawnień do udziału w posiedzeniach Rządu. Co prawda, zgodnie z Konstytucją Litwy (art. 95) w posiedzeniach Rządu bez prawa głosu może uczestniczyć wyłącznie Kontroler Państwowy ${ }^{18}$.

Należy podkreślić, że Rząd w Polsce posiada szczególne uprawnienia do wprowadzenia stanu wojennego, stanu wyjątkowego lub stanu klęski żywiołowej. Zgodnie z art. 229 i 230 polskiej Konstytucji Prezydent RP wprowadza stan wojenny lub stan wyjątkowy na wniosek Rządu, zaś na podstawie art. 232 stan klęski żywiołowej Rząd wprowadza samodzielnie. Natomiast zgodnie z Konstytucją Litwy do wprowadzenia stanu wyjątkowego (i wojennego) uprawnienia posiada Sejm (art. 67 pkt 20 i art. 144) lub Prezydent (art. 84 pkt 17 i art. 144). Rząd na Litwie nie ma zatem uprawnień konstytucyjnych do wprowadzenia stanu wyjątkowego lub stanu wojennego. Warto dodać, że pojęcie stanu klęski żywiołowej i pełnomocnictwa Rządu do jego wprowadzenia w kraju są przewidziane nie w Konstytucji Litwy, lecz w ustawie.

Wreszcie jeszcze jedna różnica w statusie prawnym rządów Litwy i Polski polega na tym, że Konstytucja RP (art. 156) przewiduje, iż ministrowie za naruszenie konstytucji lub ustaw, a także za przestępstwa popełnione w związku z zajmowanym stanowiskiem ponoszą odpowiedzialność przed Trybunałem Stanu. Jednak podobna procedura quasi-impeachmentu przed Trybunałem Stanu wobec Prezesa Rady Ministrów lub dowolnego innego ministra może być wszczęta jedynie na wniosek większości trzech piątych ustawowej liczby posłów. Natomiast zgodnie z Konstytucją Litwy nie istnieje specjalny organ quasi-impeachmentu, a procedura postawienia w stan oskarżenia w ogóle nie ma zastosowania wobec ministrów, gdyż mogą być zdymisjonowani zwykłą większością głosów posłów na Sejm.

18 Już wspomniano, że zgodnie z Konstytucją Litwy z 1922 r. Rząd składał się z Prezydenta i Gabinetu Ministrów, dlatego Prezydent Litwy miał prawo nie tylko uczestniczyć w posiedzeniach Gabinetu Ministrów, ale też im przewodniczyć. Jednak w imię sprawiedliwości należy zaznaczyć, że w czasie obowiązywania tamtej konstytucji nie była to zwyczajna praktyka. 


\subsection{Uprawnienia Prezesa Rady Ministrów i pozostałe różnice między rządami zawarte w obu konstytucjach}

Przede wszystkim, należy stwierdzić, że Konstytucja Polski nie tylko zawiera szczególny artykuł, który określa uprawnienia premiera, ale też przewiduje stanowiska wicepremierów, czyli zakłada, że w Polsce mogą występować ministrowie bez teki ${ }^{19}$. Podobnych stanowisk nie przewiduje Konstytucja Litwy. Nieobecnego lub chorego premiera na Litwie zastępuje dowolny wskazany przez niego minister. Chcąc zaś włączyć w skład Rządu ministra, który będzie regulował nową specyficzną lub węższą dziedzinę, konieczne jest utworzenie do tego osobnego ministerstwa. Tak się stało, gdy w 2009 r. Rząd konserwatystów postanowił, iż chce mieć osobnego ministra energetyki (dotąd energetyką zajmowało się Ministerstwo Gospodarki), dlatego zostało utworzone Ministerstwo Energetyki. Można tu zauważyć jeszcze jedną różnicę, a mianowicie zgodnie z Konstytucją Litwy ministra może zastępować wyłącznie inny minister (art. 98 ust. 2), natomiast w Polsce ministra zastępuje Sekretarz Stanu ministerstwa ${ }^{20}$.

Zostało już wspomniane, że art. 158 ust. 1 Konstytucji RP przewiduje mechanizm tzw. konstruktywnego wotum nieufności wobec Rządu, jednak nie istnieje on na Litwie. Oznacza to, że Sejm w Polsce, wyrażając Rządowi wotum nieufności, powinien też wskazać nazwisko kolejnego premiera, co zmusza posłów na Sejm do wykazania większego „konstruktywizmu” podczas omawiania kwestii wotum nieufności i niekierowania się wyłącznie „emocjami politycznymi”.

Należy też zaznaczyć, że w przypadkach, gdy polski Trybunał Konstytucyjny wydaje orzeczenie, które wiąże się z nakładami finansowymi nieprzewidzianymi w ustawie budżetowej, Trybunał określa termin utraty mocy obowiązującej aktu normatywnego po zapoznaniu się z opinią Rady Ministrów (art. 190 ust. 3).

I wreszcie, jeszcze jedną cechą odrębną statusu konstytucyjnego Rządu Polski jest obecność wspomnianego szczególnego artykułu (art. 148), w którym wymieniono uprawnienia Prezesa Rady Ministrów. W opinii Bogusława Banaszaka wymienione w art. 148 Konstytucji Polski pełnomocnictwa premiera uprawniają go nie tylko do przewodniczenia posiedzeniom Rady Ministrów, lecz także bycia prawdziwym kierownikiem Rządu. Natomiast Konstytucja Litwy nie wyróżnia żadnych osobnych uprawnień premiera, z wyłączeniem tego, że reprezentuje on Rząd i nim kieruje (art. 97 ust. 1). Poza tym, jak już wspomniano, premier Polski jest jednocześnie zwierzchnikiem korpusu służby cywilnej. Można jednak wyróżnić zaledwie dwa uprawnienia konstytucyjne premiera Polski, które przynajmniej formalnie nie są określone w Konstytucji Litwy: 1) premier Polski ma

19 Co ciekawe, art. 147 ust. 3 Konstytucji RP głosi, że „Prezes i wiceprezes Rady Ministrów mogą pełnić także funkcję ministra".

20 B. Banaszak, The Republic of Poland..., s. VIII-26. 
prawo samodzielnie wystąpić do Trybunału Konstytucyjnego ${ }^{21}$; 2) premier Polski ma prawo nadzoru nad administracją samorządu terytorialnego ${ }^{22}$. Różnice te nie są jednak zasadnicze, gdyż tak samo na Litwie premier de facto decyduje, czy Rząd ma wystąpić do Sądu Konstytucyjnego, a poza tym, przez swoich przedstawicieli, Rząd posiada określone dźwignie do prowadzenia nadzoru nad administracją samorządową.

\section{Wnioski}

1. Przeprowadzone badanie potwierdziło pierwotną hipotezę zakładającą, że status konstytucyjny rządów Polski i Litwy jest w istocie taki sam, co wynika z elementów stosowanej w obu krajach semiprezydenckiej formy rządów (przede wszystkim podległości bezpośrednio wybieranego Prezydenta i Rządu parlamentowi $\mathrm{w}$ państwie unitarnym), której prototyp określony jest w Konstytucji tzw. V Republiki Francuskiej z 1958 r. Na Litwie i w Polsce (tak samo jak we Francji) to właśnie Rząd oraz reprezentujący go premier (nie zaś bezpośrednio wybierany Prezydent) posiada główne pełnomocnictwa władzy wykonawczej, które wiążą się z ogólnym prowadzeniem spraw państwa poprzez realizację programu Rządu.

2. Badanie pokazało, że forma rządów w Polsce i na Litwie (w porównaniu $\mathrm{z}$ Francją) ma więcej podobieństw $\mathrm{z}$ tradycyjnym parlamentaryzmem chociażby dlatego, że w odróżnieniu od Francji w Polsce i na Litwie posłowie mogą też pełnić funkcje członków Rządu; w tych krajach wobec Rządu nie przewidziano tzw. delegowanego prawa ustawodawczego; poza tym Rząd i premier nie mają takich szerokich uprawnień w procesie ustawodawczym, jak we Francji.

3. Mimo wszystko w statusie konstytucyjnym rządów Polski i Litwy istnieją pewne nieistotne różnice, $\mathrm{z}$ których przede wszystkim należy wspomnieć szersze pełnomocnictwa premiera Polski (np. ma uprawnienia do nadzoru nad administracją samorządu terytorialnego, a ponadto jest zwierzchnikiem korpusu służby cywilnej) oraz istnienie stanowisk wicepremierów, czego nie przewiduje Konstytucja Litwy. Stanowisko wicepremiera dodaje premierowi i całemu Rządowi w Polsce elastyczności w rozwiązywaniu codziennych wyzwań politycznych kraju.

21 Na Litwie do Sądu Konstytucyjnego może wystąpić wyłącznie Rząd in corpore i zaskarżyć jedynie konstytucyjność ustaw, natomiast w Polsce premier może wystąpić w znacznie szerszym zakresie w kwestii konstytucyjności aktów, w tym umów międzynarodowych, aktów centralnych organów publicznych oraz w innych przypadkach.

22 Na Litwie kontrolą administracyjną nad samorządami (zgodnie z art. 123) zajmują się przedstawiciele Rządu, nie zaś bezpośrednio Rząd czy premier. 
4. Można też stwierdzić, że niezależnie od określonych w Konstytucji Litwy szczególnych uprawnień Rządu do przyjmowania unijnych aktów prawnych ${ }^{23}$, status konstytucyjny Rządu w Polsce jest nieco szerszy i bliższy francuskiemu prototypowi przy semiprezydenckiej formie rządów (w porównaniu z Litwą). W takim kontekście można wyróżnić kilka podobieństw między statusem konstytucyjnym Rządu w Polsce i we Francji (oraz różnic wobec statusu Rządu Litwy):

a) przewidziana w Konstytucji RP instytucja Rady Gabinetowej, na której Rządowi może przewodniczyć nie premier, lecz Prezydent, przypomina prototyp francuskiego Conseil des ministres; w Konstytucji Litwy nie ma takiej instytucji;

b) Konstytucja RP (art. 156) przewiduje, że za przestępstwa popełnione w związku z zajmowanym stanowiskiem wobec ministrów ad hoc może być stosowana procedura quasi-impeachmentu przed Trybunałem Stanu. Ta funkcjonująca w Polsce instytucja ad hoc przypomina w pewnym stopniu określone w Konstytucji Francji uprawnienia Trybunału Sprawiedliwości (franc. Cour de justice de la République), który również jest organem stosującym ad hoc wobec ministrów odpowiedzialność karną. Takich instytucji nie przewidziano natomiast $\mathrm{w}$ Konstytucji Litwy - ministrowie są tu dymisjonowani po wyrażeniu wobec nich wotum nieufności przez Sejm, a postępowanie karne może zostać wszczęte po uchyleniu immunitetu;

c) uprawnienia Rządu w Polsce, a dokładniej premiera, w kwestii wystąpienia do Trybunału Konstytucyjnego są dość szerokie (może wystąpić w sprawie konstytucyjności nie tylko ustaw, lecz także umów międzynarodowych oraz rozwiązania konfliktu wynikłego między głównymi organami publicznymi), są zatem bliższe odpowiednim uprawnieniom premiera Francji. Ponadto, Trybunał Konstytucyjny w Polsce przed wydaniem orzeczenia, które wiąże się z nakładami finansowymi nieprzewidzianymi w ustawie budżetowej, powinien skonsultować się z Rządem. Natomiast na Litwie do Sądu Konstytucyjnego może wystąpić nie premier, ale Rząd in corpore i może zaskarżyć wyłącznie konstytucyjność aktów sejmowych.

23 Akt konstytucyjny z 13 lipca 2004 r. w sprawie członkostwa Republiki Litewskiej w Unii Europejskiej stanowi część składową Konstytucji Litwy z 1992 r., „Valstybės žinios” z 2004 r., nr 11-4123. 
Santrauka

\section{Lietuvos ir Lenkijos Vyriausybès konstitucinio statuso lyginamasis tyrimas semi-prezidentinès valdymo formos kontekste}

Šiame straipsnyje yra palyginamas Lenkijos ir Lietuvos Vyriausybių konstitucinis statusas, tačiau ì ši palyginimą ịvedamas dar „trečias kriterijus”, t.y. Prancūzijos Vyriausybès konstitucinè samprata, siekiant parodyti, kaip ir kiek pirmųjų dviejų valstybių Vyriausybių statusas atitinka Prancūzijos Vyriausybès kompetenciją, veikiančią vadinamoje pusiauprezidentinejje valdymo formoje. Straipsnyje pasitvirtino pradinè hipotezè, kad Lenkijos ir Lietuvos Vyriausybių konstitucinis statusas yra labai panašus, o jo panašumas sąlygotas analogiškos valdymo formos. Straipsnyje taip pat konstatuojama, kad Prancūzijos V-osios Respublikos Vyriausybès statusas didesnę įtaką turèjo 1997 m. Lenkijos Konstitucijai, nei 1992 m. Lietuvos Konstitucijai. Šis teiginys grindžiamas šiais argumentais: Lenkijos Konstitucijoje Ministras Pirmininkas turi daugiau galių nei Lietuvos Konstitucijoje numatytas Ministras Pirmininkas; Lenkijos Konstitucijoje numatyta Kabineto taryba (Rada Gabinetowa), kuriai pirmininkauja Prezidentas, turi tam tikrų teorinių panašumų su Prancūzijos Ministrų tarybos (Conseil des ministres) statusu; Lenkijos Konstitucijoje numatytas Valstybès tribunolas (Trybunał Stanu), turintis igaliojimus taikyti baudžiamąją atsakomybę Vyriausybės narių atžvilgiu, taip pat kažkiek primena Respublikos Teisingumo teismo (Cour dejustice de la République) kompetenciją, numatyta Prancūzijos Konstitucijoje.

\section{Literatura}

Banaszak B., The Republic of Poland, [w:] C. Kortmen, J. Fleuren, W. Voermans (red.), Constitutional Law of 10 EU Member States, Warszawa 2006.

Banaszak B., The System of Government in Poland, [w:] N. Chrpnowski, T. Dronoczi, T. Takacs (red.), Governmental Systems of Central and Eastern European States, Warszawa 2011. Cairns W., McKeon R., Introduction to French Law, London 1995.

Europos Sajungos valstybiu nariu konstitucinès sistemos, Kolektyvinè mokslo studija, Vilnius 2012.

Jarašiūnas E., Prancūzijos Respublikos konstitucinè sistema, [w:] Europos Sajungos valstybiu narių konstitucinés sistemos, Vilnius 2012.

Kalinauskas G., Parlamentine kontrolè. II dalis: Praktika, Vilnius 2011.

Lietuvos konstitucinè teise. Vadovèlis, Vilnius 2012.

Šileikis E., Alternatyvi konstitucinè teise, Vilnius 2005.

Turpin D., Droit Constitutionnel, Paris 1999. 
Vaičaitis V. A., Status konstytucyjny prezydentów Litwy i Polski, [w:] D. Górecki (red.), Instytucja prezydenta w polskim i litewskim prawie konstytucyjnym, Łódź 2017.

\section{Akty prawne}

Akt konstytucyjny z 13 lipca 2004 r. w sprawie członkostwa Republiki Litewskiej w Unii Europejskiej, „Valstybės žinios” z 2004 r., nr 11-4123.

Konstytucja Republiki Francuskiej z 1958 r. Texte intégral en vigueur à jour de la révision constitutionnelle du 23 juillet 2008, https://www.conseil-constitutionnel.fr/le-bloc-de-constitutionnalite/texte-integral-de-la-constitution-du-4-octobre-1958-en-vigueur (dostęp: 20.10.2018).

Konstytucja Republiki Litewskiej z 1992 r. „Valstybės žinios” z 1992 r., nr 33-1014. Aktualna wersja: http://www3.lrs.lt/home/Konstytucja/Konstytucja.htm (dostęp: 20.10.2018).

Konstytucja Rzeczpospolitej Polskiej z 2 kwietnia 1997 r., Dz.U. z 1997 r., nr 78, poz. 483.

Tymczasowa ustawa podstawowa Republiki Litewskiej, „Valstybės žinios” z 1990 r., nr 9-224. 